JAZYKOVEDNÝ ČASOPIS, 2013, roč. 64, č. 2

\title{
ROZHL'ADY
}

\section{FERDINAND DE SAUSSURE $(1857-1913)^{1}$}

\author{
SLAVOMÍR ONDREJOVIČ \\ Jazykovedný ústav Luudovíta Štúra SAV, Bratislava
}

\begin{abstract}
ONDREJOVIČ, Slavomír: Ferdinand de Saussure (1857 - 1913). Journal of Linguistics, 2013, Vol. 64, No 2, pp. 151 - 197. (Bratislava)
\end{abstract}

\begin{abstract}
The paper reminds some facts of the Ferdinand de Saussure's life, which could have influenced his posthumously published work Course in General Linguistics (1916). The attention is also paid to his other work Mémoire sur le système primitif des voyelles dans les langues indo-européennes (1879) which has played a role in the development of structural linguistics as well. The author shows that it is useful to go back (also critically) to all thoughts and premises of Ferdinand de Saussure even after 100 years. We still can, as it is also proved by F. Čermák, find there new stimuli and inspirations and, moreover, reveal a loopholes or unclear points that need another and more adequate interpretation.

Key words: Ferdinand de Saussure, life and work of F. de Saussure, Ferdinand de Saussure and Noam Chomsky
\end{abstract}

1.1 22. februára 2013 uplynulo práve 100 rokov od smrti legendárneho švajčiarskeho jazykovedca Ferdinanda de Saussura (nar. 26. novembra 1857 v Ženeve). Ide pritom nielen o nespochybnitel’ného fundátora lingvistického štrukturalizmu a semiotiky, ale aj jedného z najvýznamnejších zjavov novovekých dejín vôbec. Takmer všeobecná zhoda je dokonca v tom, že Ferdinand de Saussure je zakladatel'om celej modernej lingvistiky (Szemerényi, 1971, Culler, 1986, s. 99). Podl'a Františka Čermáka, jedného z prekladatel'ov a najlepších znalcov jeho diela (porov. napr. Čermák, 2007, 2013), sa dodnes nenarodil iný taký človek, ktorý by mu bol roveň. A to napriek tomu, že Ferdinand de Saussure svoje zakladatel'ské dielo Kurz všeobecnej lingvistiky nikdy nenapísal - vyšlo až tri roky po jeho smrti v roku 1916.

\section{${ }^{1}$ Poznámka redakcie jazykovedného časopisu:}

Príspevok venovaný osobnosti Ferdinanda de Saussura zarad’ujeme do tohto čísla časopisu ako vyjadrenie pocty životu a dielu jednej z najvýznamnejších osobností lingvistiky, no zároveň ho chápeme ako ,podnet k d’alším návratom k myšlienkovému svetu Ferdinanda de Saussura, ako výzvu neuspokojovat' sa s tradovanými interpretáciami jeho téz, výrokov a pojmov, aj ako stimul ku konfrontácii ducha tohto sveta s preskriptívnym zaobchádzaním so spisovným jazykom s odvolávaním sa na výdobytky systémovej lingvistiky, na počiatku ktorej je práve de Saussure“ (z posudku recenzenta). Uvítali by sme, keby tento príspevok vyvolal diskusiu o systémovej lingvistike - o jej prameňoch, smerovaní, ako aj o premenách a motiváciách jej starších i súčasných interpretácií. 
Vzniklo len, ako je takisto všeobecne známe, na základe poznámok jeho žiakov Charlesa Ballyho a Alberta Sechehayeho. Na učenie Ferdinanda de Saussura nadviazalo a aj dnes nadväzuje množstvo lingvistických škôl, ale jeho výrazný vplyv sa prejavil i za hranicami lingvistiky: vo filozofii, sociológii, psychológii, v psychoanalýze, antropológii, etnológii, literárnej vede a i. Niet pochýb, že F. de Saussure zásadne zmenil pohl'ad jazykovedcov na jazyk (a predstavitel'ov d’alších spomínaných vied na predmet ich výskumu²), otvoril novú paradigmu, pričom jeho základné postuláty a dištinkcie boli prijaté tak univerzálne, že dnes sa autorstvo týchto výrokov už ani nepripomína (porov. Čermák, 2013, s. 64).

Ferdinand de Saussure už v ranom veku preukazoval výnimočný talent na jazyky (v mladíckom veku ovládal nemčinu, francúzštinu, angličtinu, latinčinu a gréčtinu), ale už vtedy prekvapoval aj výbornou schopnost'ou abstraktného myslenia ${ }^{3}$. Ako 15-ročný pripravil rukopis s názvom Rozprava o jazykoch (Pokus o zredukovanie gréckych, latinských a nemeckých slov na malý počet koreňov). Najčastejšie sa Ferdinand de Saussure vo všeobecných encyklopédiách a popularizujúcich dejinách svetovej jazykovedy, ale aj v iných prácach (porov. napr. Harris, 2001; Piller, 2013), označuje ako „otec modernej lingvistiky“. Uvedený titul však niektorí d’alší autori pripisujú americkému jazykovedcovi, filozofovi, politickému aktivistovi i jednému z najcitovanejších autorov súčasnosti Noamovi Chomskému (nar. 1928). Touto poslednou charakteristikou tvorí spomínaný autor kontrapunkt k F. de Saussurovi, ktorý sa počas svojho života určite nemohol pýšit' takýmto prvenstvom. Z podstaty veci vyplýva, že Saussurov „,̌as“ prišiel až podstatne neskôr. Pravdaže, de Saussure a ani Chomsky nenašli uznanie u všetkých. Spomeňme v tejto súvislosti aspoň to, že Witold Mańczak (1970) pripisuje dokonca Saussurovmu dielu zodpovednost' za dnešnú krízu v jazykovede (komentár porov. u Komárka, 1970), kým napr. Gabriel Altmann Chomského generatívnu gramatiku vo viacerých príspevkoch nazýva „degeneratívnou gramatikou“ (porov. viac k tomu Ondrejovič, 2011). Pripomeňme aj to, že aj ked' Roman Jakobson vysoko hodnotil Saussurovu dištinkciu medzi syntagmatickými a asociatívnymi (paradigmatickými) vzt’ahmi, konštatoval i to, že Saussurov Kurz všeobecnej lingvistiky obsahuje početné chyby, protirečenia a nebezpečné zjednodušenia (porov. aj Harris, 2001). Ale ako by sa mohol vyhnút' chybám, protirečeniam a zjednodušeniam text, ktorý autor nikdy nezredigoval, ba ho nikdy ani nevidel? Dôležité však zrejme je, že bol „epochálne inšpiratívny“, ináč by ho zrejme t’ažko prirovnávali ku Galileovi Galileimu (Cassirer, 1945), Mikulášovi Koperníkovi, Albertovi Einsteinovi či Isaacovi Newtonovi (Koerner, 1972)

${ }^{2}$ Napr. aj pre Clauda Lévi-Straussa bol Saussurov pohlad na jazyk ako synchrónny systém znakov, kde hodnota každého znaku vyplýva z jeho vzt’ahov a postavenia voči ostatným znakom, podla vlastných slov skutočným „osvietením“. Tento zakladatel sociálnej antropológie to s vel'kým úžitkom uplatnil najmä pri štúdiu tzv. primitívnych (predpísomných) náboženských kultúr.

${ }^{3} \mathrm{O}$ jeho odvekej zál'ube $\mathrm{v}$, antitézach“ už od prvých rokov štúdia porov. u Tullia de Maura (v českej verzii u F. Čermáka, 2007, na s. 262). 
(viac k tomu Čermák, 2013, k obrane Saussura voči kritike Pražského lingvistického krúžku porov. zasa Čermák, 1997).

1.2 Nikto nepochybuje, dokonca ani Saussurovi kritici, že bol mimoriadnym zjavom. Svoju rolu v jeho vývine zohralo bezpochyby prostredie vtedajšej Ženevy, kam z Francúzska pred storočiami ušli pred náboženským besnením jeho protestantskí predkovia (hugenoti). Ale tvorivo a podnetne sa pod jeho zrenie v mladosti určite podpísalo aj užšie rodinné zázemie. Sám Ferdinand de Saussure bol predstavitel'om piatej generácie známych učencov $\mathrm{v}$ tejto rodine ${ }^{4}$. $\mathrm{Z}$ jeho predkov sa najčastejšie spomína starý otec Horace Bénédict, profesor filozofie a prírodných vied, otec Henri, významný zoológ, geológ, entomológ a politik, a strýko Theodore, ktorý bol okrem iného známy aj ako historik so záujmom o jazyk. Jeden zo Saussurových bratov bol uznávaným maliarom, druhý sinológom a syn Raymond zasa významným švajčiarskym psychoanalytikom, prvým prezidentom švajčiarskej psychoanalytickej federácie.

2.1 F. de Saussure vstúpil v roku 1872 vo veku iba necelých 15 rokov do Académie (premenovanej neskôr na Ženevskú univerzitu), kde si vybral na štúdium iba nie dlho predtým objavený sanskrit, no venoval sa aj gótčine a starej hornej nemčine. V 18 rokoch vstupuje do Parížskej jazykovednej spoločnosti, v ktorej sa neskôr (v dvadsat'pät'ke) stáva tajomníkom. Aj ked' sa na Ženevskej univerzite na želanie rodičov zapísal pôvodne na kurzy fyziky a chémie, jazykoveda ho prit’ahovala stále silnejšie. Preto nie je nič neočakávané, že v r. 1876 zamieril na štyri roky do jedného z vtedajších centier európskej jazykovedy, do Lipska. Tu vo veku 21 rokov publikuje známe Mémoire (1879), dodnes jednu z dôležitých prác indoeuropeistiky, ktorá, žial', zostala po celý život jeho jedinou knižne vydanou prácous. Pritom jej výnimočnost' nebola „uznaná“ okamžite po vyjdení, autor si musel najprv prejst' obdobím žiarlivého odmietania a nepriatel'stva najmä zo strany niektorých mladších lipských

${ }^{4} \mathrm{~K}$ dejinám saussurovského rodu porov. takisto najmä u T. de Maura (1973, cit. podl’a českého vydania Kurzu všeobecnej lingvistiky F. Čermáka, 2007, s. 257 - 260). U tohto autora možno nájst’ podrobné informácie nielen o osudoch Ferdinanda de Saussura a o jeho pôsobení na univerzitách, ale aj o osudoch a recepcii Kurzu v rôznych krajinách, o vnímaní de Saussura v rôznych prúdoch lingvistiky a podrobne sa preberá aj otázka predchodcov F. de Saussura - to všetko sa dopĺn̆a aktuálnymi poznámkami prekladatel'a.

${ }^{5}$ Plný názov: Mémoire sur le systeme primitif des voyelles dans les langues indoeuropéens (Rozprava o prvotnom systéme vokálov v indoeurópskych jazykoch). Ide o vel'mi inšpiratívne indoeuropeistické dielo, ktoré podnietilo vznik tzv. laryngálnej teórie, rozpracovanej neskôr Jerzym Kurylowiczom a Emilom Benvenistom. Je to teória o vzniku indoeurópskeho vokalizmu (sčasti aj konsonantizmu), založená na tom, že niektoré javy možno vysvetlit' len pomocou istých predpokladaných (na príslušných miestach vo vývoji už zaniknutých) hlások, tzv. laryngál. Vlastne aj problém, ktorý F. de Saussure riešil na tomto mieste, t. j. to, ako potvrdit hypotézy o neznámych jazykových javoch na základe známych javov, mal vplyv na rozvoj štrukturalizmu. Už tu nachádzame v zárodku teoretickú predstavu o protikladovej a relačnej povahe jazykových entít. Saussurove predpoklady o existencii prapôvodných sonantických koeficientov/laryngál a ich vývoji sa definitívne potvrdil o 50 rokov neskôr po náleze a rozlúštení chetitčiny (Bedřich Hrozný). 
profesorov. Zrejme aj preto v roku 1880 po obhájení dizertácie prechádza do Paríža na École practique des hautes études, kde ostal pôsobit' 11 rokov. Tu rýchlo zažiari a po jednom roku sa vo veku 24 rokov stáva mimoriadnym profesorom indoeurópskej jazykovedy (popri starogermánskych jazykoch prednášal v tom čase aj litovčinu a latinčinu). V Paríži bol poverený prednáškami z porovnávacej gramatiky a mal viest' i katedru porovnávacej jazykovedy, čo automaticky súviselo s vymenovaním za riadneho profesora. Nedošlo $\mathrm{k}$ tomu $\mathrm{v}$ zásade $\mathrm{z}$ administratívnych dôvodov, lebo podmienkou bolo, aby prijal francúzske občianstvo. $Z$ toho dôvodu sa v roku 1891 F. de Saussure vrátil spät’ do Ženevy (Čech, 2007).

$2.2 \mathrm{~V}$ uvedenom (parížskom i „druhom“ ženevskom) období však prekvapujúco publikuje iba pár článkov a recenzií, no - ako je zrejmé - vel’mi intenzívne sa zamýšl’a nad základnými teoretickými otázkami jazykovedy. Svoje všeobecnojazykovedné úvahy a „postrehy“ o jazyku dlho nepublikuje, čo mu zrejme umožňovala aj skutočnost', že podl'a všetkého sa vtedy ešte vo vede nepresadilo heslo ,publish or perish" a nijaká agentúra nehodnotila jeho schopnost' adekvátne zastávat' profesorské miesto na univerzite na základe kvantitatívnych kritérií ${ }^{\text {. }}$

V roku 1907 - vo svojich 50 rokoch (!) - odprednášal napokon aspoň prvý zo svojich troch legendárnych kurzov zo všeobecnej jazykovedy. Druhý kurz potom prišiel na rad v rokoch 1908/1909 a tretí v rokoch 1910/1911. Ako sa dozvedáme od F. Čermáka, tieto kurzy navštevoval však pomerne malý počet študentov (v prvom bolo pät' až šest', v druhom jedenást' a v tret’om dvanást' poslucháčov), pričom väčšina $\mathrm{z}$ nich ani neštudovala lingvistiku. Takmer šokujúco dnes pôsobí informácia, že Charles Bally a Albert Sechehaye, ktorí vydali onen slávny Kurz všeobecnej lingvistiky na základe svojich poznámok z prednášok, na tie prednášky vel'mi ani nechodili. Nečudo, že si pritom museli pomáhat’ zápiskami od iných, najmä Alberta Riedlingera. František Čermák o tejto prvej podobe textu sa iste oprávnene domnieva, že by sa aj vzhl'adom na dlhoročné pochybnosti a neistoty autorovi nepáčil. Slovenskí čitatelia majú dnes to štastie, že majú k dispozícii „upravené“ české vydanie Kurzu (3. vydanie z r. 2007), ktoré je jednou z najbohatších studníc poznania

${ }^{6}$ Nad jeho nechut'ou písat' sa zamýšlali viacerí autori (porov. k tomu aspoň Villani; 1990, Piller, 2013), ktorí vo svojich úvahách vychádzali z niektorých poznámok v Saussurovej korešpondencii s Wilhelmom Streitbergom, jedným zo zakladajúcich editorov periodika Indogermanische Forschungen. V listoch, ktoré mu de Saussure adresoval v rokoch 1892 - 1903, sám spomína svoju „nevyliečitel'nú grafofóbiu“ (,incurable graphophobe“) a svoj „odpor k písaniu“ (,horreurr d écrire“) a priznáva sa, že „každé písanie mu spôsobuje nevýslovné muky“. Ale ako je možné, že niekto, kto napísal vo veku 25 rokov spomínané bravúrne Mémoire sur le systeme primitif des voyelles dans les langues indoeuropéens, už potom nikdy nenapísal nič významné? W. Streitberg to (v liste Karlovi Brugmannovi) hodnotí ako dôsledok jeho ,unheilbarer Geisteskrankheit“. Antoine Meilet Saussurovu nechut' publikovat' však posudzuje omnoho zmierlivejšie a, zdá sa, objektívnejšie - ako dôsledok jeho perfekcionizmu. V každom prípade však vinou týchto „prieł’ahov“ nemáme k dispozícii taký Kurz, na ktorý by sám autor dal imprimatur, a zrejme z toho istého dôvodu sú hodnotenia a interpretácie Saussurovho diela také odlišné a diverzita štrukturalistických škôl, ktoré rozvíjali jeho „dedičstvo“, taká pestrá. 
Saussurovho Kurzu i okolností, ktoré predchádzali jeho vzniku či mali vplyv na jeho podobu, i tých, ktoré určovali „posmrtný život“ Kurzu v najrozmanitejších školách. Okrem spol'ahlivého a presného prekladu nájdeme v tomto vydaní Čermákov zasvätený komentár k Saussurovmu dielu a odtláčajú sa tu aj známe Bibliografické a kritické poznámky o Ferdinandovi de Saussurovi od Tullia de Maura, aktuálne doplnené o poznámky prekladatel’a (Františka Čermáka). Sú tu aj podrobné komentáre $\mathrm{k}$ de Saussurovi z pohl'adu 21. storočia, no aj dodatky a úryvky z rukopisov autora a zápiskov študentov, ale aj vel'mi podrobný register. Boli časy, ked’ sme sa všetci (azda okrem romanistov) na Slovensku museli uspokojit' iba s úryvkami Kurzu v ruštine, ktoré vyšli u Vladimira A. Zveginceva v Dejinách jazykovedy 19. a 20. storočia v náčrtoch a výtahoch $(1964)^{7}$. Vd’aka najmä spomínanému Čermákovmu vydaniu sa dnes „saussurovská“ situácia zmenila do istej miery aj u nás (porov. $\mathrm{k}$ tomu Sekvent, 2011). Bude preto zrejme užitočné aj na tomto mieste zreprodukovat', resp. rozvinút' aspoň niektoré zistenia zo Saussurovho vnímania jazyka a jeho „okolia“" s opretím sa najmä na interpretáciu F. Čermáka.

3.1 Ferdinand de Saussure o jazyku tvrdil, že jeho základy majú psychickú povahu a sú uložené v mozgu, jazykový znak je psychická jednotka zjednocujúca pojem (signifié) a akustický obraz (signifiant), pričom akustický obraz je psychickým obrazom fyzicky realizovaného zvuku, ktorý je vzájomne spätý s pojmom (akustický obraz evokuje pojem, a naopak, porov. k tomu Dolník, 2009, s. 23 n.). Zároveň má aj svoju sociálnu dimenziu. Keby sme podla de Saussura mohli obsiahnut' celý úhrn verbálnych obrazov uchovávaných u všetkých jednotlivcov, „,ospeli by sme k sociálnemu zväzku, ktorým sa jazyk vytvára. Je to zásobnica, ktorú praxou svojho hovorenia naplńajú členovia toho istého spoločenstva, je to gramatický systém, ktorý existuje v mozgu každého, či presnejšie v mozgoch súhrnu jednotlivcov. Jazyk totiž v nijakom z nich nie je úplný a dokonalý a existuje len v mase“ (de Saussure, 2007, s. 50) ${ }^{8}$.

Aj ked' jazyk používa podla F. de Saussura každý a vyjadrujú sa o ňom takmer všetci, málokto si uvedomuje zložitost' súhry jazyka jednak s myslením, ktoré má podl'a neho amorfnú povahu, ale aj s jeho prechodom do jazykových zvukov. Vel'mi zložitá je operácia, pri ktorej sa plastické myslenie pretavené do slov ukladá do jednej línie, do tzv. lineárnej ret’aze. Aby jazyk mohli používat' všetci používatelia v zásade rovnakým spôsobom, priznáva sa mu konvenčnost', ktorá sa opiera o úzus. Z toho vychádza aj Saussurovo chápanie znaku. A z poznania, že každý jazyk sa ako živý organizmus neustále vyvíja, dospieva Saussure k svojej, ako to formuluje F. Čermák, „prvej a zásadnej“ dichotómii synchrónie a diachrónie. Sám pritom na

\footnotetext{
${ }^{7}$ Ruský (Suchotinov) preklad Saussurovho diela vyšiel s rozsiahlym úvodom O. Šorovej už v r. 1933, ale ten u nás z pochopitel’ných príčin nebol dostupný. Neskôr to bolo vydanie A. A. Cholodoviča, ktoré sa objavilo pod názvom Trudy po jazykoznaniju (Moskva: Progress 1977).

${ }^{8}$ Citácie z Čermákovho českého prekladu Saussurovho Kurzu všeobecnej lingvistiky (2007) uvádzame vo vlastnom preklade po slovensky.
} 
viacerých miestach upozorňuje, že kým v synchrónii platí, že jazyk je systém znakov, v diachrónii, ktorá predstavuje následnost' viacerých stavov jazyka, systémom nie je. Diachrónia pozostáva zo sledu historicky a časovo sa striedajúcich stavov, ktoré v jednom rámci nemožno porovnávat'. Synchrónny stav jazyka naproti tomu pre svojich hovoriacich existuje prostredníctvom úzu - na rozdiel od diachrónie, ktorú synchrónny hovoriaci už nepozná a nepouživa. Podl'a de Saussura jazyk pritom „svoje jednotky, ktoré sú mu dané, nikdy neprestáva interpretovat' a rozkladat““ (v preklade F. Čermáka, 2007, s. 197). Na tomto mieste sa pripájame k Čermákovmu povzdychu, že je škoda, že bez povšimnutia ostala brilantná Saussurova poznámka, že v jazyku ,existuje len to, čo sa vycit’uje. Čo sa nevycituje, je gramatikovým výmyslom" (Englerova edícia, cit. podl’a F. Čermáka, 2007, s. 122, 165). Niet pritom pochýb, že vel'ké množstvo pravidiel a poučiek v oficiálnych príručkách aj u nás (na Slovensku) je kontraintuitívne. Frapantné je to najmä pri „nových“ pravidlách slovenského pravopisu, ktoré mali ambíciu rozšírit’ pravidlo o rytmickom krátení v slovenskom jazyku, čím však zaviedli v zásade umelé tvary, ktoré v reči t’ažko niekto „uhádne“ (viac k tomu Ondrejovič, 2011, s. 310)9.

3.2 Zaujímavá je aj otázka systému, ktorá v Saussurovom Kurze prekvapujúco nemá osobitný paragraf. Dozvedáme sa, že jazyk je systém znakov a že sa týka len synchrónie. Základom systému je usporiadanost' a systém je teda usporiadaný celok. Aj Magdalena Zawisławska si však položila otázku, či to naozaj tak rigorózne funguje v prirodzenom jazyku v každom ohl'ade. Jazyk je bezpochyby usporiadaný celok ako každý iný systém, o tom niet pochýb, ale už i Ch. Bally, Saussurov nástupca na Katedre všeobecnej jazykovedy a sanskritu na Ženevskej univerzite, upozorňuje, že systémovost’ tu nie je absolútna: „V systéme je všetko medzi sebou svojím spôsobom previazané a toto poznanie, sformulované Saussurom, nestratilo ani dnes svoj význam. Bolo by však vel'kou chybou, keby sa toto presvedčenie stalo základom koncepcie jazyka ako symetrickej a harmonickej konštrukcie“ (cit. podl'a Zawisławskej, 2013). Všeobecne je známy aj výrok Viléma Mathesia, že jazykový systém je značne komplexný jav, ktorý nikdy nebýva v úplnej rovnováhe. Preto budú podl’a neho „príliš logické a preto príliš zjednodušujúce sústavy vždy trochu zlyhávat"“ (Mathesius, 1936, s. 50). A napokon sa oplatí zacitovat' v tejto súvislosti i Františka Daneša, ktorý v doslove ku knihe Jazyk ako nabitá zbraň (2008) pripomína, s odkazom na Christiana Uhlenbecka a Dwighta Bolingera, že ,... jazyk rozhodne nie je vysoko organizovaný systém, ale fenomén len systematický, avšak pružný, vždy k dispozícii na tvorivé použitie“ (Daneš, 2008, s. 244). Nerešpektovanie tohto poznania súvisí s hyperbolizáciou analogistického princípu. Krajná situácia nastáva zrejme vtedy, ked” „nútime“ jazyk (v Saussurovom duchu vlastne aj reč) prostredníctvom kodifikačných príručiek, aby bol systematický aj tam, kde systematický nie je,

${ }^{9}$ Špeciálny prieskum „odhalil“, že súčasnú kodifikovanú podobu odvodených tvarov „,dial'karský“, „dial'karského“ či napr. „vol’nomyšlienkarský“, „,vol’nomyšlienkarského“ z respondentov nebol takmer nikto schopný zvládnut” v zhode s ,platnou kodifikáciou“. 
aspoň nie podl'a predpísaného vzoru, a kde vidiet', že sa mu do toho ani vel'mi nechce (porov. Ondrejovič, 2011, s. 310).

3.3 Ferdinand de Saussure rozlišuje d’alej medzi tým, čo je nám bezprostredne prístupné, a tým, čo je za tým. V prvom prípade ide podl'a všetkého o jednotky prehovorové, textové, v druhom o jednotky systémové, z ktorých sú tie prvé odvodené a vytvorené, hoci daný prípad treba vnímat' najskôr ako „,vzájomnú“ odvodenost'. V Saussurovej terminológii ide v tomto prípade o parole (reč) a langue (jazyk); jedno i druhé sa od jazyka k jazyku líši a vytvára pestrost' a rôznost' jazykov. Langue a rovnako aj parole majú svoju sociálnu, ale aj individuálnu stránku. Langue vo svojej sociálnej dimenzii je intersubjektívne platný a sociálne sformovaný konvenčný systém (,fait social“), prítomný v hlavách hovoriacich. Vo svojej individuálnej dimenzii predstavuje mentálnu hodnotu (,dépôt“), je subjektívnou projekciou jazyka. Aj pojem parole má dve dimenzie: na jednej strane sa vníma ako konkrétny rečový akt, t. j. ako individuálna realizácia langue jednotlivým hovoriacim, resp. ako časovo-priestorová realizácia systému, na druhej strane je to však aj miesto „štartu“ zmien, ktoré sa objavujú i v langue.

Saussure pritom zdôrazňuje, že jazykové jednotky nemajú nijaký materiálny základ (okrem fonetického) a sú to iba abstrakcie (,jazyk nie je substancia, ale forma“, ,jazyk je forma, a nie substancia“, ,jazyk je systém čistých hodnôt“, ,jazyk je súbor abstrakcií"). K langue, ku psychike nositel'ov jazyka, nemáme priamy prístup, a teda jediný „,čisto“ lingvistický prístup spočíva v jeho rekonštrukcii na základe analýzy toho, čo je priamo pozorovatel'né, teda reči, v terminológii Juraja Dolníka komunikátu. Od tohto postulátu de Saussure prechádza, ako upozorňuje F. Čermák, k svojmu d'alšiemu základnému tvrdeniu, že jazyk je zložený zo znakov, že je to znakový systém, pričom Saussure na viacerých miestach zdôrazňuje, že tento systém znakov sa líši od iných znakových sústav a je teda svojou povahou jedinečný ${ }^{10}$. Rozlíšením signifiant (označujúceho) a signifié (označovaného) rozlišuje i dve hlavné stránky znaku, poukazujúc na to, že je arbitrárny (resp. konvenčný). Sám však pritom v niektorých prípadoch hovoril aj o obmedzenej arbitrárnosti znaku: „Základný princíp arbitrárnosti znaku nebráni v rozlišovaní toho, čo je v každom jazyku radikálne arbitrárne, t. j. nemotivované, a toho, čo je také len relatívne. Iba čast' znakov je absolútne arbitrárna: u iných dochádza k javu, ktorý umožňuje v arbitrárnosti rozlišovat' stupne, a nepotlačovat' ich pritom: znak môže byt' relatívne motivovaný“ (Saussure, cit. podl'a Čermák, 2007, s. 160).

${ }^{10}$ Saussure v tejto súvislosti hovorí aj toto: „Predpisy určitého zákonníka, náboženské obrady, námorná signalizácia atd'. vždy zamestnávajú len určité množstvo jednotlivcov naraz a počas vymedzenej doby: naproti tomu pri jazyku sa v každom okamihu zúčastňuje každý, a preto je tiež pod neustálym vplyvom všetkých. Tento hlavný fakt na preukázanie nemožnosti nejakej revolúcie postačí. Zo všetkých spoločenských inštitúcií ponúka jazyk najmenšiu možnost' využit' iniciatívu“ (Saussure, 2007, s. 103). Nie je preto isté, či je adekvátne s odkazom na F. de Saussura tvrdit', že norma, ,ktorá sa najevidentnejšie manifestuje v kodifikácii jazyka“ a má v tomto chápaní blízko k systému, predstavuje „dirigujúcu silu vo vzt’ahu k úzu, k oblasti používania jazykových prostriedkov“ (Kočiš, 1977, s. 66). V každom prípade je sporné odvodzovat' niečo také zo Saussurových slov. 
3.4 Práve touto charakterizáciou synchrónneho systému, ktorý sa zaoberá súhrou významových rozdielov (opozícií), zavádza Saussure do lingvistiky d’alší nový pohl'ad, totiž že za jazykovou jednotkou, znakom nič nie je, o nič sa neopiera, ale je vždy daný súborom špecificky individuálneho súboru protikladov (diferencií), ktoré má $\mathrm{k}$ iným jednotkám ${ }^{11}$. Sledovanie jazykovej produkcie, produktov hovoru, resp. l'udských prehovorov zložených z menších jednotiek, ktoré majú lineárnu povahu, a zároveň toho, že každá z týchto jednotiek niekam trvalo patrí a tvorí s podobnými jednotkami (s rovnakou funkciou či významom) jasné hierarchizované triedy (porov. Čermák, 2013, ibid.), privádza de Saussura k postulovaniu d’alšej základnej dichotómie syntagmatický (relevantný najmä pre parole) a paradigmatický, asociativny (relevantný v zásade pre langue). Túto dištinkciu považoval F. de Saussure podla F. Čermáka za natol'ko zásadnú, že vyhlásil v protiklade $\mathrm{k}$ tradícii, že „dištinkcie medzi syntagmatickými a asociatívnymi vzt’ahmi naznačuje spôsob triedenia, ktorý sa ponúka sám od seba a ktorý je jediný, ktorý možno klást’ do základu gramatického systému“ (Saussure, 2007, s. 165). F. Čermák z toho vyvodzuje, že aj z uvedeného je zrejmé, kde sa nachádza dnešná lingvistika a kde má svoje manká: syntagmatická lingvistika svojím novším záujmom v oblasti štúdia korpusu o syntagmatiku začína iba nesmelo vznikat' vedl'a tradičnej orientácie výlučne na paradigmatiku. Oboje je však podl'a F. Čermáka len lingvistika systému (langue) a lingvistika parole doteraz vlastne neexistuje. F. de Saussure hovoril o lingvistike jazyka (ako základnom predmete jazykovedy) i lingvistike reči, tú druhú však už zrejme nestačil rozvinút'.

Vedl'a základných dištinkcií langue/parole však F. de Saussure postuluje tretiu jednotku, langage (zvyčajne prekladanú ako rečová činnost'), ktorá je im nadradená. Dichotómia (jazyk/reč) nemusí byt' terminologicky úplne adekvátna - podl'a F. Čermáka sa uplatňuje zo zotrvačnosti pod vplyvom „sovietskych zjednodušení“. Pražská škola pôvodnú trichotómiu langue/parole/langage prekladala ako jazyk/(pro) mluva/řreč (v slovenčine by asi mohlo byt' jazyk/prehovor/reč $)^{12}$. Nie je však isté, či je možné už zafixované pojmoslovie po sto rokoch týmto spôsobom modifikovat'.

Pritom pre vývoj jazyka je podl'a Saussura zásadné parole, lebo, ako sme už spomenuli, práve tu vznikajú všetky jazykové zmeny, z ktorých niektoré sa ustal'ujú, stávajú sa súčastou langue, čím sa vcelku mení celý jazyk. Tieto zmeny sa odohrávajú v strete anomálii (nepravidelných zmien) a analógií, ktoré udržujú kontinuitu jazyka. Vzniká pritom tzv. saussurovský paradox, ktorý sa dá stručne vyjadrit’ otázkou: ako môžu hovoriaci efektívne používat' jazyk, ked’ sa neustále mení, inými slo-

${ }^{11}$ Hoci tu Saussure hovorí o opozíciách a hierarchickom systéme, princíp opozičných štruktúr sa naplno presadzuje až u Nikolaja Sergejeviča Trubeckého.

${ }^{12}$ Doplňme ešte, že terminologicky sa k tomu chápaniu približuje u nás Luudovít Novák (1933), vlastne člen Pražského lingvistického krúžku, ktorý o Saussurovi napísal, že „rozoznáva zretel’ne jazyk (langue) od reči (language) a najmä vravy (parole), z ktorých iba vrava má skutočnú existenciu individuálnu (reč je schopnost’ človeka hovorit’ vôbec, jazyk zasa istý jazykový systém niektorého sociálneho kolektíva)“(s. 99). 
vami: ako môžu jazykom komunikovat', ked' je zároveň ohniskom zmeny, presnejšie, ohniskom vel'kého počtu zmien (porov. k tomu Labov, 1972, k riešeniu porov. Trask, 1996). Je tu teda podl’a F. Čermáka teoreticky nie celkom vyjasnený problém, ktorý však prax očividne bez problémov rieši. Možno však upozornit' na to, že k zmenám môže dôjst' v systéme jazyka bez väššej úhony preň zrejme preto, že sa uskutočňujú prostredníctvom variácí́ a tie sú prítomné v reči permanentne, aj ked' ich kodifikácia často potláča. Ich permanentná prítomnost' je dokonca základnou charakteristikou reči (Trask, 1996, s. 281). Stojí za to aspoň ešte pripomenút', ako často a v akých rozmanitých súvislostiach hovorieval F. de Saussure o potrebe metódy a metodológie, ktorú vždy odvodzoval z povahy skúmaného materiálu. Opakovane zdôrazňoval pritom dôležitost' zaujímaného hladiska implikujúceho možnost' a pluralitu iných hl'adísk (pohl'ad na Alpy za Ženevským jazerom sa mení podl'a toho, kde stojíme). Rád pritom siahal aj k obrazným prirovnaniam (porov. napr. Zawisławska, 2013). Z nich je určite najznámejšie „podobenstvo“, kde sa jazyk a reč (hovor) prirovnáva $\mathrm{k}$ šachovej hre, ktorá stojí v protiklade ku konkrétnej partii (Saussure, 2007, s. 116 - 117). Mnohí autori poukazujú na isté nepresnosti tejto analógie a ponúkajú svoje riešenia. Boris Majer ponúka napr. analógiu medzi jazykom a futbalom, ktorá podl'a neho lepšie ilustruje rozdiel medzi jazykom a rečou (pravidlá futbalu vs. spôsob, ako sa odohrá zápas, taktika, štýl a i.). Iné sú Saussurove metafory o symfónii, divadle, o gobelíne, liste papiera a d’alšie.

3.5 Čo sa týka pojmu spisovný jazyk, upozornime aj na to, že jazykovú jednotu možno podl'a F. de Saussura rozrušit', ked' „prirodzený konkrétny jazyk podl'ahne vplyvu spisovného jazyka“. Dochádza k tomu podl'a neho spol'ahlivo zakaždým, ked' ,určitý národ dospeje do istého stupňa civilizácie“. Spisovným jazykom tu rozumie „,nielen jazyk literatúry, ale všeobecnejšie všetky druhy kultivovaného jazyka, či už oficiálneho alebo nie, ktorý slúži celej spoločnosti“" (de Saussure, 2007, s. 221), prirodzeným konkrétnym jazykom zasa myslí najskôr tzv. l'udový jazyk. Ako mimoriadne poučený lingvista o minulosti i súčasnosti jazykov si dobre uvedomoval jedinečnú povahu jazyka ako špecifickej spoločenskej inštitúcie a poznajúc aj l'udské aktivity vo vzt’ahu k jazyku sa vyjadril, že ,väčšina inštitúcií sa dá prerábat', v istých okamihoch opravovat' a aktom vôle reformovat', kým v jazyku je, ako vidiet', taký čin nemožný a ani akadémie nemôžu svojimi dekrétmi chod nastúpený inštitúciou, ktorú nazývame jazyk, menit““ (porov. Čermákove vybrané pasáže z 3. kurzu, cit podl'a Saussure, 2007, s. 435). Tento citát pochádza až zo zápiskov E. Constantina a v Kurze nie je zachytený, no je vel'mi dôležitý. Podl'a F. Čermáka sa tu so živým jazykom zráža aktuálna obsesia preskriptivistov, ktorá má dlhú tradíciu aj v českej tradícii, ale, dodajme, omnoho rigoróznejšiu podobu u nás. Ide pritom o pokusy ,jazyk menit“, „,vylepšovat" a „predpisovat' ho v rozpore s inými faktami“. Už aj pri výklade o komplexnej povahe systému a o neschopnosti l'udí menit' ho de Saussure v Kurze uvádza, že práve tí, ktorí ho používajú denne, prejavujú jeho hlbokú neznalost' a ,takú zmenu si možno predstavit' len v dôsledku zásahu špecialistov, gramati- 
kov, logikov atd', avšak skúsenost’ nám ukazuje, že podobná intervencia nemala nijaký úspech" (Saussure, 2007, s. 102 - 103). Podl'a F. Čermáka sme sa od F. de Saussura v tejto veci vel'mi nepoučili a máme čo doháňat'. Saussure pojem preskripcia sám nepožíval. Bolo pri jeho iných záujmoch ,zrejme pod jeho dôstojnost' zaoberat' sa takouto efemérnou, neobjektívnou a problematickou l'udskou činnost'ou“ (Čermák, 2013, s. 165).

4.1 Je prospešné, ako novšie ukázal aj F. Čermák, vracat' sa (súhlasne i kriticky) k jednotlivým úvahám a premisám Ferdinanda de Saussura aj po 100 rokoch po jeho odchode. Stále v ňom môžeme nachádzat' nielen nové podnety a inšpirácie, ale objavovat’ aj „biele“ či nejasné miesta, ktoré potrebujú d’alšiu, adekvátnejšiu interpretáciu.

\section{Bibliografia}

CASSIRER, Ernst: Structuralism in Modern Linguistics. In: Word, 1, 1945, s. 99 - 120.

CULLER, Jonathan: Ferdinand de Saussure. Revised edition. New York: Corwell University Press 1986. $158 \mathrm{~s}$.

ČECH, Radek: Ferdinand de Saussure. In: Moderní lingvistika a zázrak jazyka. Dostupné na: http://www.gasbag.wz.cz/tema/rocnik2/cislo2/obsah.htm

ČERMÁK, František: Synchrony and Diachrony Revisited: Was R. Jakobson and the Prague Circle Right in their Criticisme of the Saussure? In: Folia Linguistica Historica, 7, 1997, No. 1 -2, s. 29 - 40.

ČERMÁK, František: Ferdinand de Saussure a jeho Kurs. In: de Saussure, Ferdinand: Kurz obecné lingvistiky. Přeložil F. Čermák. Praha: Odeon 2007, s. 15 - 28.

ČERMÁK, František: Ferdinand de Saussure. Jak ho známe (a neznáme) sto let po jeho smrti. In: Časopis pro moderní filologii, 2013, roč. 95, č. 2, s. $155-168$.

DANEŠ, František: Doslov. In: Dwight Bolinger: Jazyk jako nabitá zbraň. Užívání a zneužívání jazyka v naší době. Prel. do češtiny L. Weinbergerová. Praha: Petr Zima 2008, s. 241 - 249.

DOLNÍK, Juraj: Všeobecná jazykoveda. Opis a vysvetl’ovanie jazyka. Bratislava: Veda 2009.

de MAURO, Tullio: Ferdinand de Saussure, Cours de linguistique générale. Paris: Payot 1973, v českom preklade In: Ferdinand de Saussure: Kurs obecné lingvistiky. 3. vyd. Praha: Academia 2007, s. $257-428$.

de SAUSSURE, Ferdinand: Mémoire sur le système primitif des voyelles dans les langues indo-européennes, Leipzig 1879 (bez uvedenia vydavatel'a).

de SAUSSURE, Ferdinand: Cours de linguistique générale. Publié par Ch. Bally et A. Sechehaye avec la collaboration de A. Riedlinger, Paris 1916, 2. vyd. 1922, 3. vyd. 1931, 4. vyd. 1949, 5. vyd. 1959. 6. vyd. 1972.

de SAUSSURE, Ferdinand: Kurs obecné lingvistiky. Vydal Charles Bally a Albert Sechehaye za spolupráce Alberta Riedlingera. Komentáře napsal Tulio de Mauro. Přeložil, doplnil a poznámkami opatřil František Čermák. 3. vyd. Praha: Academia 2007.

DROZDÍK, Ladislav: Jazyk a jazykoveda v postmodernom myslení (Prípad Derrida). Jazykovedný časopis, 2002, roč. 53, č. 1, s. 3 - 17 .

HARRIS, Roy: Saussure and his Interpreters. New York, University Press 2001 (2. vyd. 2003).

KOČIŠ, František: Jazyková norma. Kultúra slova, 1977, roč. 11, č. 3, s. 65 -70.

KOMÁREK, Miroslav: K jedné kritice de Saussura. Slovo a slovesnost, 1972, roč. 28, č. 3, s. 540 $-241$.

LABOV, Wiliam: Sociolinguistic Patterns. Philadelphia, University of Pennsylvania Press 1972. $362 \mathrm{~s}$. 
MAJER, Boris: Strukturalizem. Poskus filozofske kritike. Ljubljana: Delo 1971.

MAŃCZAK, Witold: Critique du structuralisme. In: Folia Linguistica, 1970, roč. 3, č. 3 - 4, s. 169 -177 .

ONDREJOVIČ, Slavomír: Ešte raz o kauze -ar, -aren̆. In: Vidy jazyka a jazykovedy. Na počest' Miloslavy Sokolovej. Ed. M. Ološtiak, M. Ivanová, D. Slančová. Prešov: Filozofická fakulta Prešovskej univerzity 2011, s. $308-325$.

ONDREJOVIČ, Slavomír: Jubileum prof. Gabriela Altmanna. Jazykovedný časopis, 2011, roč. 62 , č. 1 , s. $149-158$.

NOVÁK, L’udovít: Fonologia a štúdium slovenčiny. Slovenská reč, 1933, roč. 2, č. 4, s. 97 - 100.

PILLER, Ingrid: Saussure, the procrastinator. October 30, 2013. Dostupné na: http://www. languageonthemove.com/multilingual-academics/saussure.

SEKVENT, Karel: Perspektívy saussurizmu v jazykovede I. Pramene. Jazykový znak. In: Jazyk a kultúra, 2011, č. 6.

SZEMERÉNYI, Oswald: Richtungen der modernen Sprachwissenschaft. Teil I. Von Saussure bis Bloomfield, 1916 - 1950. Heidelberg, Carl Winter, Universitätsverlag 1991.

TRASK, Robert Lawrence: Historical Linguistics. London: Arnold 1996.

VILLANI, Paola: Documenti saussuriani conservanti a Lipsia e Berlino. In: Cahiers Ferdinand de Saussure, 1990, roč. 44, s. 3 - 33 .

ZAWISŁ AWSKA, Magdalena: Język i metafora. Dostupné na: http//zawislawska. com/2013/03/13/język-i-metafora

ZVEGINCEV, Vladimir A.: Istorija jazykoznanija XIX - XX vekov v očerkach i izvlečenijach, čast' I. Moskva: Nauka 1964, s. $353-411$. 